\title{
Inhibition of invasion and epithelial-mesenchymal transition of human breast cancer cells by hydrogen sulfide through decreased phospho-p38 expression
}

\author{
MIN LV $^{1 *}$, YAN LI $^{2 *}$, MING-HUA JI ${ }^{3}$, MING ZHUANG $^{2}$ and JIN-HAI TANG ${ }^{4}$ \\ ${ }^{1}$ Department of Scientific Research, Nanjing Medical University Affiliated Cancer Hospital, \\ Cancer Institute of Jiangsu Province, Nanjing, Jiangsu 210009; \\ ${ }^{2}$ Department of Oncology, Lianyungang First People's Hospital, Lianyungang, Jiangsu 222002; \\ Departments of ${ }^{3}$ Radiotherapy and ${ }^{4}$ General Surgery, Nanjing Medical University Affiliated Cancer Hospital, \\ Cancer Institute of Jiangsu Province, Nanjing, Jiangsu 210009, P.R. China
}

Received July 29, 2013; Accepted January 21, 2014

DOI: $10.3892 / \mathrm{mmr} .2014 .2161$

\begin{abstract}
Sodium hydrosulfide (NaHS) is an exogenous hydrogen sulfide $\left(\mathrm{H}_{2} \mathrm{~S}\right)$-releasing molecule and has antitumor potential against a wide variety of human cancer types. The effect of exogenous $\mathrm{H}_{2} \mathrm{~S}$ on the invasion of breast cancer and the possible underlying mechanisms remain unknown. The present study aimed to investigate the in vitro effects of $\mathrm{H}_{2} \mathrm{~S}$ on transforming growth factor- $\beta 1$ (TGF- $\beta 1$ )-induced human breast cancer cells and the associated mechanisms. MCF-7 cells were incubated with TGF- $\beta 1$ to induce epithelial-mesenchymal transition (EMT) and an MTT assay was performed to detect cell viability. Flow cytometry, using propidium iodide (PI) staining, was used to determine the stages of the cell cycle. Apoptosis was detected with Annexin V-fluorescein isothiocyanate and PI double staining. Western blotting was performed to detect the protein expression of cystathionine $\gamma$-lyase (CSE, an endogenous $\mathrm{H}_{2} \mathrm{~S}$ producer), phospho-p38 (a signaling protein associated with apoptosis), and SNAI1 (Snail, associated with the induction of EMT). A Boyden chamber invasion assay was performed to detect tumor invasion. The results demonstrated that when NaHS was administered to TGF- $\beta 1$-treated MCF-7 cells, the cells exhibited decreased proliferation, G0/G1 phase cell cycle arrest and increased apoptosis. NaHS treatment following TGF- $\beta 1$ administration also resulted in decreased cell invasion and decreased EMT, which was indicated by decreased
\end{abstract}

Correspondence to: Professor Jin-Hai Tang, Department of General Surgery, Nanjing Medical University Affiliated Cancer Hospital, Cancer Institute of Jiangsu Province, 42 Baiziting, Nanjing, Jiangsu 210009, P.R. China

E-mail: jschtjh@126.com

*Contributed equally

Key words: breast cancer, hydrogen sulfide, transforming growth factor- $\beta 1$, apoptosis, invasion, epithelial-mesenchymal transition
Snail protein expression. In addition, incubation with NaHS increased endogenous CSE protein expression and decreased p38 mitogen-activated protein kinase phosphorylation in MCF-7 cells stimulated by TGF- $\beta 1$. Furthermore, the inhibition of endogenous CSE by DL-propargylglycine increased EMT in the MCF-7 cells treated with NaHS and TGF- $\beta 1$. In conclusion, the present study provides insights into a novel anticancer effect of $\mathrm{H}_{2} \mathrm{~S}$ on breast cancer cells through activation of the $\mathrm{CSE} / \mathrm{H}_{2} \mathrm{~S}$ pathway and decreased expression of phospho-p38.

\section{Introduction}

Hydrogen sulfide $\left(\mathrm{H}_{2} \mathrm{~S}\right)$ gas exhibits numerous physiological and pathological effects. $\mathrm{H}_{2} \mathrm{~S}$ is endogenously produced from L-cysteine by cystathionine $\gamma$-lyase (CSE) and cystathionine $\beta$-synthase in mammalian tissues, and endogenous hydrogen sulfide exists in the sodium hydrosulfide (NaHS, 2/3) and $\mathrm{H}_{2} \mathrm{~S}(1 / 3)$ forms (1). $\mathrm{H}_{2} \mathrm{~S}$ has been demonstrated to exert a therapeutic effect in a wide range of diseases, including neuronal injury (2), hypertension (3), myocardial infarction (4) and hypoxic pulmonary hypertension (5). In addition, $\mathrm{H}_{2} \mathrm{~S}$ exhibits antigrowth potential against a wide variety of human cancer cells (6). In breast cancer cells, $\mathrm{H}_{2} \mathrm{~S}$ decreased the in vivo tumor mass through the inhibition of cellular proliferation, induction of apoptosis and decrease in nuclear factor- $\kappa \mathrm{B}(\mathrm{NF}-\kappa \mathrm{B})$ levels (7). Furthermore, $\mathrm{H}_{2} \mathrm{~S}$ has been found to inhibit breast cancer-induced osteoclast formation and activity, suppress osteoclastogenesis and prevent osteolysis (8). As bone metastases are common in breast cancer, $\mathrm{H}_{2} \mathrm{~S}$ may have inhibitory effects on breast cancer cell invasion and metastasis, thereby suppressing osteoclastogenesis and osteolysis. However, there are few studies concerning the anti-invasive effect of $\mathrm{H}_{2} \mathrm{~S}$ on cancer cells, including breast cancer cells.

The invasion of breast cancer is a multi-stage process that involves abnormal signaling by transforming growth factor- $\beta$ (TGF- $\beta$ ). TGF- $\beta$ acts as a tumor suppressor in the early stages of carcinogenesis, but in late-stage breast cancer it promotes invasion and metastatic dissemination (9). Moreover, TGF- $\beta$ acquires a proinvasive effect in the advanced stages of breast cancer 
through a complex process known as epithelial-mesenchymal transition (EMT) (10). $\mathrm{H}_{2} \mathrm{~S}$ has been found to attenuate EMT in human alveolar epithelial cells (11). Moreover, $\mathrm{H}_{2} \mathrm{~S}$ has been reported to inhibit the pathogenesis of pulmonary and hepatic fibrosis, and suppress the migration of human lung fibroblasts, all of which involve the EMT process (12-14). Therefore, it was hypothesized that $\mathrm{H}_{2} \mathrm{~S}$ may act as a suppressor of EMT in breast cancer and exhibit antitumor and anti-invasive effects.

In the present study, breast cancer cells were incubated with TGF- $\beta 1$ to induce an EMT phenotype. The effects of $\mathrm{NaHS}$, an $\mathrm{H}_{2} \mathrm{~S}$-releasing molecule, on cell viability, cell cycle, apoptosis, invasion and EMT were investigated. The protein expression of CSE and phospho-p38 in breast cancer cells treated with TGF- $\beta 1$ was also analyzed.

\section{Materials and methods}

Cell culture. MCF-7 human breast cancer cells were purchased from the cell bank of the Institute of Biochemistry and Cell Biology, Shanghai Institutes for Biological Sciences, Chinese Academy of Sciences (Shanghai, China). The cells were cultured with high glucose Dulbecco's modified Eagle's medium (Invitrogen Life Technologies, Carlsbad, CA, USA) supplemented with $10 \%$ fetal bovine serum (Sijichun Bioengineering Materials Inc., Hangzhou, China), 100 U/ml penicillin and $100 \mathrm{mg} / \mathrm{ml}$ streptomycin at $37^{\circ} \mathrm{C}$ in a humidified $5 \% \mathrm{CO}_{2}$ incubator. After cultured cells reached $70 \%$ confluence, the cells underwent trypsinization and were subcultured with a 1:3 split ratio in new culture flasks. DL-propargylglycine (PPG, Sigma, St. Louis, MO, USA), an inhibitor of CSE, was used to inhibit endogenous $\mathrm{H}_{2} \mathrm{~S}$ in MCF-7 cells.

Cell viability assay. An MTT (Sigma Chemical Co., St. Louis, MO, USA) assay was performed to determine cell viability. Briefly, cells in suspension at the logarithmic growth phase were added to each well of 96-well culture plates at a density of $1 \times 10^{3}$ cells $/ \mathrm{ml}$, with $100 \mu \mathrm{l}$ cell suspension in each well. The cells were incubated for $24 \mathrm{~h}$ at $37^{\circ} \mathrm{C}$ in a humidified atmosphere with $5 \% \mathrm{CO}_{2}$. They were then incubated with TGF- $\beta 1(100 \mathrm{ng} / \mathrm{ml})$ or recombinant human TGF- $\beta 1$ (100 ng/ml, R\&D Systems Inc., Minneapolis, MN, USA) with different concentrations of NaHS (0, 100, 200 and $500 \mu \mathrm{mol} / \mathrm{l}$; Sigma Chemical Co.). Following treatment for 12, 24, 48 and $72 \mathrm{~h}, 10 \mu \mathrm{l}$ of $5 \mathrm{mg} / \mathrm{ml}$ MTT solution was added to each well and the plates were incubated at $37^{\circ} \mathrm{C}$ for $4 \mathrm{~h}$. Following centrifugation at $1,409 \mathrm{x} \mathrm{g}$ for $10 \mathrm{~min}$, the formazan pellets were isolated by discarding the supernatant and then dissolved completely in $100 \mu 1$ dimethylsulfoxide (DMSO), agitating the plates for $10 \mathrm{~min}$. The optical density (OD) at $570 \mathrm{~nm}$ wavelength was measured using an ELISA plate reader (Ricso RK201; Shenzhen Ricso Technology Co., Ltd., Shenzhen, China) to determine the quantity of pellet.

Cell cycle analysis. MCF-7 cells in the logarithmic growth phase were cultured in serum-free medium for $24 \mathrm{~h}$. They were then incubated with TGF- $\beta(100 \mathrm{ng} / \mathrm{ml})$ and/or $500 \mu \mathrm{mol} / \mathrm{l}$ $\mathrm{NaHS}$ for $24 \mathrm{~h}$. The cells were harvested by trypsinization and following washes with cold phosphate-buffered saline (PBS), the cells were fixed in cold $70 \%$ ethanol. Finally, $1 \mu \mathrm{l}$ propidium iodide (PI) staining solution (containing $20 \mathrm{mg} / \mathrm{ml} \mathrm{PI}$ and $1 \mathrm{mg} / \mathrm{ml}$ RNAse) was added to the samples. The distribu- tion of cells in each phase of the cell cycle was measured and analyzed by flow cytometry (FACScan; Becton-Dickinson, San Francisco, CA, USA). The percentage of cells in the G0/G1, S and G2/M phases were calculated. Results were acquired from 10,000 cells.

Apoptosis assay. MCF-7 cells were randomly divided into four groups: Control, NaHS (500 $\mu \mathrm{mol} / \mathrm{l}), \mathrm{TGF}-\beta(100 \mathrm{ng} / \mathrm{ml})$ and TGF- $\beta+\mathrm{NaHS}$. Following incubation for $24 \mathrm{~h}$, at least $2 \times 10^{5}$ cells were harvested from each group for the apoptosis assay. Subsequent to centrifugation at $626 \mathrm{x} \mathrm{g}$ for $5 \mathrm{~min}$ and washing with PBS buffer, the pellet was resuspended in $100 \mu \mathrm{l}$ of $1 \mathrm{X}$ binding buffer and incubated with $2.5 \mu \mathrm{l}$ Annexin $\mathrm{V}$ and $5 \mu \mathrm{l}$ PI (at a final concentration of $10 \mu \mathrm{g} / \mathrm{ml}$ ). After incubation in the dark for $30 \mathrm{~min}$, apoptosis was immediately determined by FACScan flow cytometry and the associated data were analyzed using Lysis II software (Becton Dickinson). At least 10,000 events were analyzed for each sample.

Cell migration assay. The in vitro invasion capability of MCF-7 cells was measured by Boyden chamber assay with matrigel (BD Bioscience, Bedford, MA, USA) in 24-well tissue culture plates with Transwell ${ }^{\circledR}$ filter membranes (5 $\mu \mathrm{m}$ pore; Costar, Boston, MA, USA). The lower sides of the filters were coated with type I collagen $(0.5 \mathrm{mg} / \mathrm{ml})$ and the lower section of the filter contained low-serum media. In each well, $5 \times 10^{4}$ cells were resuspended in $100 \mu \mathrm{l}$ DMEM media and seeded in the upper part of a Transwell ${ }^{\circledR}$ plate. The cells were then incubated with NaHS (500 $\mu \mathrm{mol} / \mathrm{l})$ and/or TGF- $\beta$ (100 $\mathrm{ng} / \mathrm{ml})$ for $24 \mathrm{~h}$. Subsequent to the removal of the cells on the upper surface of the filter, the cells that had migrated to the lower part were stained with hematoxylin and eosin (Sigma Chemical Co.) and counted under an inverted light microscope (Olympus IX70; Olympus Optical Co., Ltd., Tokyo, Japan; magnification, x200) as the number of migrated cells (invasion index). Each sample was analyzed in triplicate and repeated twice.

Western blot analysis. MCF-7 cells were cultured with NaHS $(500 \mu \mathrm{mol} / \mathrm{l})$ and/or TGF- $\beta(100 \mathrm{ng} / \mathrm{ml})$ for $24 \mathrm{~h}$. The cell proteins were then extracted and a bicinchoninic acid protein concentration assay kit (Beijing Biosea Biotechnology Co., Ltd., Beijing, China) was used to determine their concentrations. The cell lysates $(50 \mu \mathrm{g})$ were resolved in $15 \%$ sodium dodecyl sulfate-polyacrylamide gels and electrophoretically transferred to a polyvinylidene difluoride membrane (Bio-Rad, Hercules, CA, USA). The membrane was blocked with 5\% skimmed milk powder in Tris-buffered saline containing $0.05 \%$ Tween-20 at room temperature for $2 \mathrm{~h}$. It was then incubated with primary mouse antibodies against SNAI1 (Snail) protein, CSE or phospho-p38 (Santa Cruz Biotechnology, Inc., Santa Cruz, CA, USA), followed by horseradish peroxidase-conjugated rabbit anti-mouse secondary antibody (Santa Cruz Biotechnology, Inc.) at 1:1,000 dilutions for $2 \mathrm{~h}$ at room temperature. Enhanced chemiluminescence (Pierce ${ }^{\circledR}$ ECL Plus Western Blotting Substrate; Pierce Biotechnology, Inc., Rockford, IL, USA) was used to visualize the protein blots and $\beta$-actin served as an internal control.

Measurement of $\mathrm{H}_{2} \mathrm{~S}$ concentration in cell culture media. To measure the concentration of $\mathrm{H}_{2} \mathrm{~S}, 500 \mathrm{ml}$ culture media from 
A

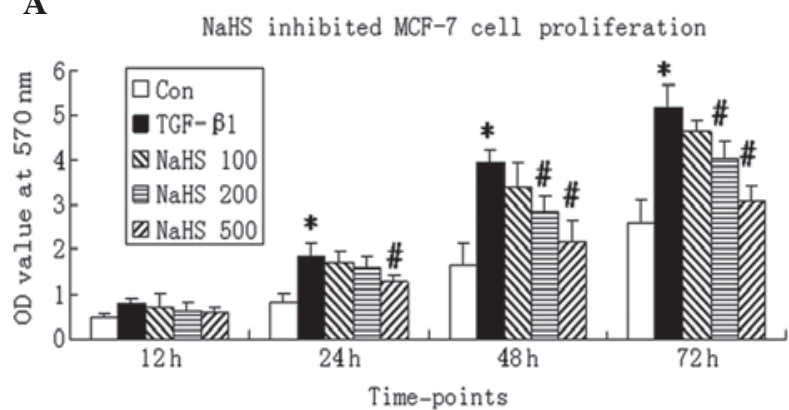

C

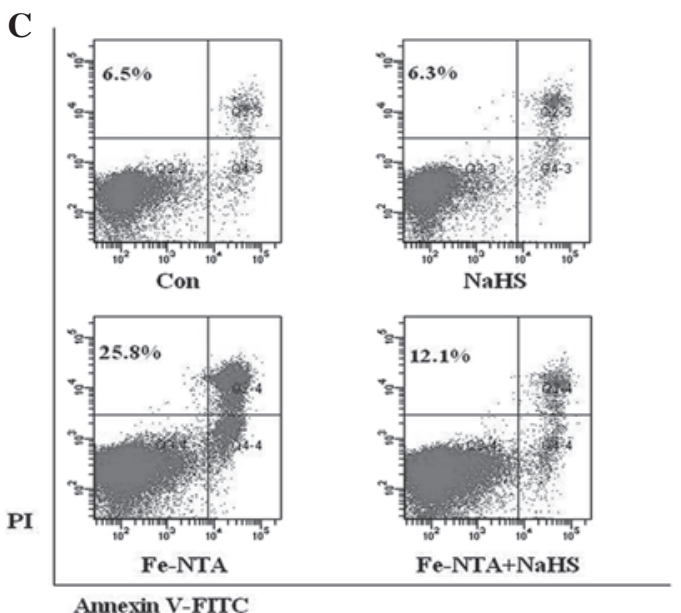

B

Effect of NaHS on the cell cycle distribution of MCF-7 cells

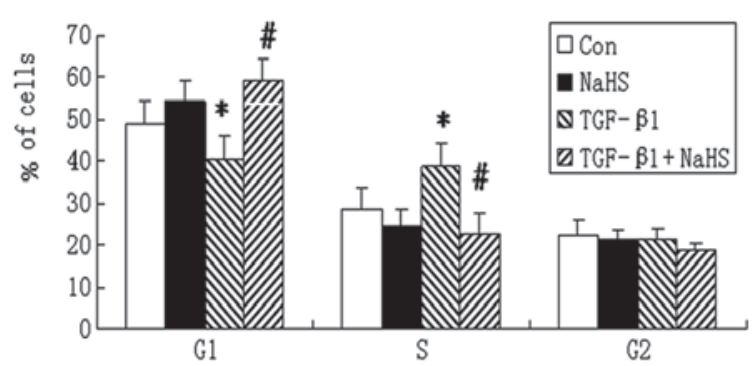

D

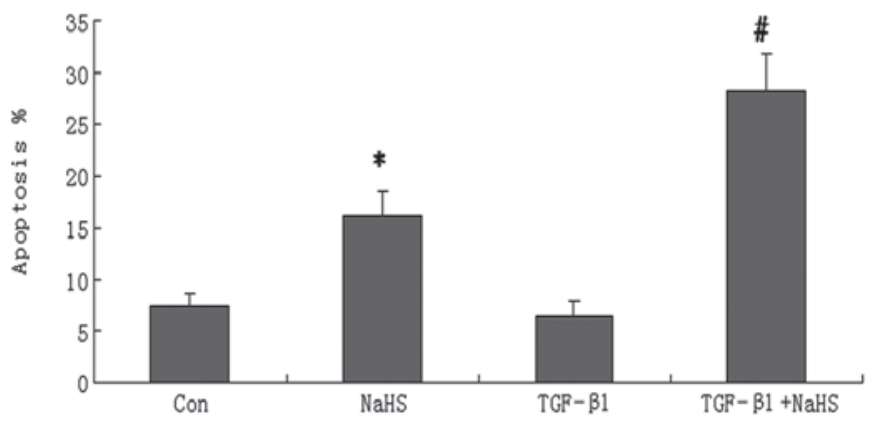

Figure 1. Effect of sodium hydrosulfide (NaHS) on cell viability, cell cycle and apoptosis in MCF-7 breast cancer cells induced by transforming growth factor- $\beta 1$ (TGF- $\beta 1$ ). (A) NaHS inhibited the proliferation of TGF- $\beta 1$-treated MCF-7 cells. MCF-7 cells were seeded in 96 -well culture plates at a density of $1 \times 10^{3}$ cells $/ \mathrm{ml}$. After adherence, cells were incubated with PBS (Control group, Con), TGF- $\beta 1$ (100 ng/ml, TGF- $\beta 1$ group), TGF- $\beta 1$ plus various concentrations of $\operatorname{NaHS}(0,100,200$ or $500 \mu \mathrm{mol} / \mathrm{l})$. Following incubation for 12, 24, 48 and $72 \mathrm{~h}$, an MTT assay was performed to determine cell viability. At least three independent experiments were conducted. Data are presented as optical density (OD) values at $570 \mathrm{~nm}$ wavelength. (B) MCF-7 cells were cultured in serum-free medium for $24 \mathrm{~h}$, and then were incubated with PBS (Con), NaHS (500 $\mu \mathrm{mol} / \mathrm{l})$, TGF- $\beta 1$ (100 ng/ml), and TGF- $\beta 1+\mathrm{NaHS}$ for $24 \mathrm{~h}$. Propidium iodide (PI, $20 \mu \mathrm{g} / \mathrm{ml}$ ) staining was performed to determine the percentages of cells in the G0/G1, S and G2/M phases. (C) MCF-7 cells were randomly divided into control, NaHS, TGF- $\beta 1$ and TGF- $\beta 1+\mathrm{NaHS}$ groups. Annexin V-fluorescein isothiocyanate (FITC) and PI double staining was performed to detect cell apoptosis using flow cytometry $24 \mathrm{~h}$ following treatment. NaHS treatment increased the apoptotic rate in MCF-7 cells regardless of whether they were treated with TGF- $\beta 1$. Representative images from three experiments are shown. (D) Apoptotic rates from the control, NaHS, TGF- $\beta 1$ and TGF- $\beta 1+$ NaHS groups. The Annexin $\mathrm{V}^{+} / \mathrm{PI}^{-}$and Annexin $\mathrm{V}^{+} / \mathrm{PI}^{+}$populations were considered to represent apoptotic cells. A two-tailed, unpaired t-test was performed to compare the differences between two groups. Data are presented as the mean \pm standard deviation. ${ }^{*} \mathrm{P}<0.05$, vs. the control group (Con). "P<0.05, vs. the TGF- $\beta 1$ group.

each group was mixed with $425 \mathrm{ml}$ distilled water in a microtube containing zinc acetate $(1 \% \mathrm{w} / \mathrm{v} ; 250 \mathrm{ml})$. N,N-dimethyl-pphenylenediamine sulphate $(20 \mathrm{mM} ; 133 \mathrm{ml})$ in $7.2 \mathrm{M} \mathrm{HCl}$ was subsequently added, followed by $\mathrm{FeCl}_{3}(30 \mathrm{mM} ; 133 \mathrm{ml})$ in $1.2 \mathrm{M}$ $\mathrm{HCl}$. Trichloroacetic acid $(10 \% \mathrm{w} / \mathrm{v} ; 250 \mathrm{ml})$ was then used to precipitate any protein. The OD value of the resulting solution was measured using a 96-well microplate reader at $670 \mathrm{~nm}$ wavelength (Tecan Group Ltd., Männedorf, Switzerland).

Statistical analysis. All quantitative data are presented as the mean \pm standard deviation. SPSS version 14.0 (SPSS, Inc., Chicago, IL, USA) was used for statistical analysis. The statistical significance of difference between two groups was determined by Student's t-test (unpaired, two tailed) and $\mathrm{P}<0.05$ was considered to indicate a statistically significant difference.

\section{Results}

NaHS inhibits MCF-7 cell growth induced by TGF- $\beta 1$. The MCF-7 cells were incubated with TGF- $\beta(100 \mathrm{ng} / \mathrm{ml})$, then treated with various concentrations of NaHS $(0,100,200$ and $500 \mu \mathrm{mol} / \mathrm{l}$ ) for 12, 24, 48 and $72 \mathrm{~h}$. MCF-7 cells treated with PBS served as a control. The MTT assay revealed that compared with the control, TGF- $\beta$ treatment promoted cell proliferation and increased cell viability in a time-dependent manner. However, NaHS inhibited cell viability in the MCF-7 cells treated with TGF- $\beta$ in a dose- and time-dependent manner. NaHS exhibited the most potent effect on cell viability at a $500 \mu \mathrm{mol} / 1$ concentration at all time-points (Fig. 1A). Therefore, in subsequent experiments, a concentration of $500 \mu \mathrm{mol} / \mathrm{l}$ was used for NaHS treatment of the cells.

Cell cycle distribution was analyzed by flow cytometry to investigate the detailed mechanism of the antiproliferative activity of NaHS. The MCF-7 cells were treated with NaHS $(500 \mu \mathrm{mol} / \mathrm{l})$ and/or TGF- $\beta$ (100 ng/ml) for $24 \mathrm{~h}$. The TGF- $\beta$ treatment decreased the percentage of cells in the G0/G1 phase and increased the percentage of cells in the $\mathrm{S}$ phase. NaHS increased the percentage of cells in the G1 phase significantly, while decreasing the percentage of cells in the $S$ phase in TGF- $\beta$-treated MCF-7 cells $(\mathrm{P}<0.05)$. However, no change was found in the percentage of cells in the $\mathrm{G} 2$ phase following TGF- $\beta 1$ or NaHS treatment (Fig. 1B). This assay indicated that 


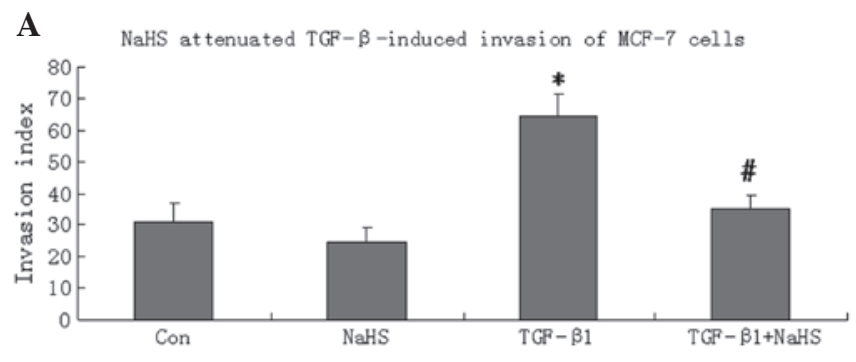

B

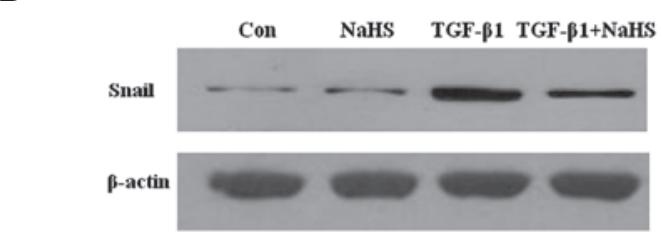

C

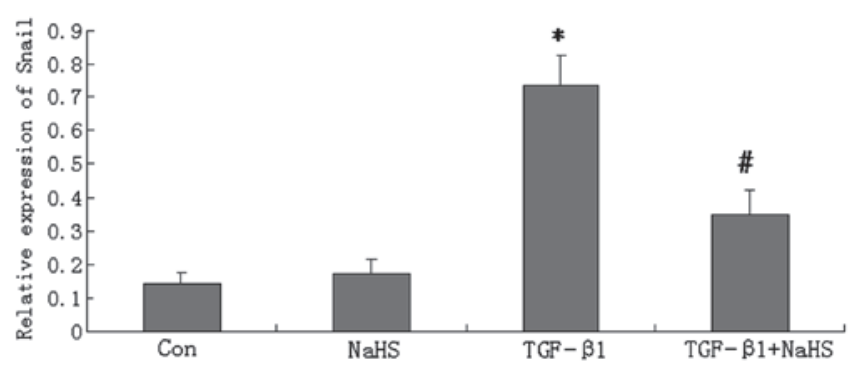

Figure 2. Sodium hydrosulfide (NaHS) inhibited MCF-7 breast cancer cell invasion and the expression of epithelial-mesenchymal transition (EMT) marker protein SNAI1 (Snail) induced by transforming growth factor- $\beta 1$ (TGF- $\beta 1)$. (A) The proinvasive effect of TGF- $\beta(100 \mathrm{ng} / \mathrm{ml})$ was analyzed by a Boyden chamber assay. MCF-7 cells were incubated with NaHS $(500 \mu \mathrm{mol} / \mathrm{l})$ and/or TGF- $\beta$ (100 ng/ml) for $24 \mathrm{~h}$. Cells treated with Dulbecco's modified Eagle's medium media served as a control (Con). Cell invasion was enhanced by TGF- $\beta$ treatment, which was attenuated by NaHS. (B) Whole cell extracts of MCF-7 cells immunoblotted with antibody against human Snail protein. $\beta$-actin served as a loading control. Representative immunoblots from three independent experiments are shown. (C) The relative expression of Snail in the four groups. A two-tailed, unpaired t-test was performed. The Y co-ordinate indicates the grey value of Snail normalized to that of $\beta$-actin. Data are expressed as the mean \pm standard deviation. ${ }^{*} \mathrm{P}<0.05$, vs. the control group (Con). ${ }^{.} \mathrm{P}<0.05$ vs. the TGF- $\beta 1$ group.

NaHS inhibited cell proliferation by inducing G0/G1 phase arrest in MCF-7 cells treated with TGF- $\beta 1$.

To investigate whether a decrease in cell viability was a result of the proapoptotic effect of NaHS, an apoptosis assay was performed in MCF-7 cells by double staining with Annexin V-fluorescein isothiocyanate and PI. It was found that TGF- $\beta 1$ treatment alone did not change the apoptotic rate of MCF-7 cells. However, treatment with NaHS increased the apoptotic rate regardless of whether the cells had been treated with TGF- $\beta 1$ ( $\mathrm{P}<0.05$, Fig. $1 \mathrm{C}$ and D). Furthermore, MCF-7 cells treated with TGF- $\beta 1$ and NaHS demonstrated a higher apoptotic rate than control cells, which indicates that induction with TGF- $\beta 1$ may enhance sensitivity to NaHS.

NaHS decreases cell invasion and EMT induced by TGF- $\beta 1$. To investigate whether NaHS can inhibit the migration of breast cancer cells, the invasive capability of MCF-7 cells was determined by a Boyden chamber invasion assay. The cells were incubated with TGF- $\beta 1$ to induce an invasive state,
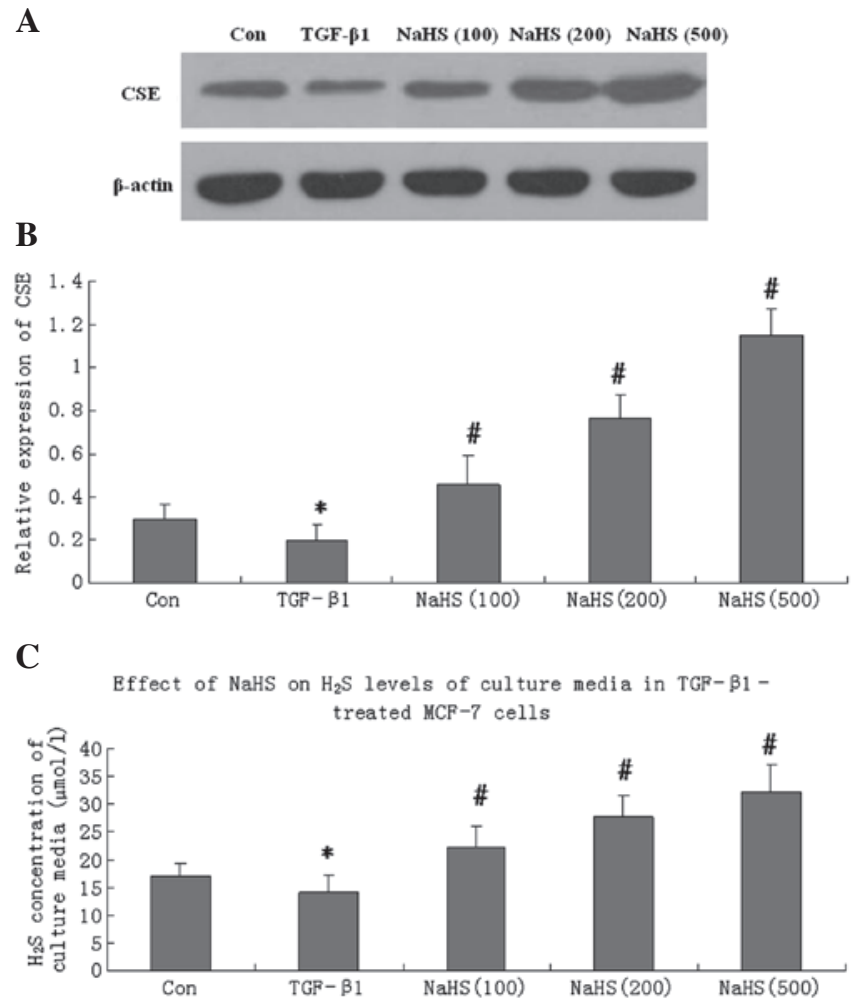

Figure 3. Effects of sodium hydrosulfide (NaHS) on cystathionine $\gamma$-lyase (CSE) protein expression in MCF-7 cells. MCF-7 cells were incubated with transforming growth factor- $\beta$ (TGF- $\beta, 100 \mathrm{ng} / \mathrm{ml}$ ) and different concentrations of NaHS $(0,100,200$ and $500 \mu \mathrm{mol} / \mathrm{l})$ for $24 \mathrm{~h}$. Cells treated with Dulbecco's modified Eagle's medium media served as a control (Con). NaHS increased the CSE protein levels in a concentration-dependent way in TGF- $\beta 1$-induced MCF-7 cells. (A) Whole cell extracts of MCF-7 cells were immunoblotted with antibody against human CSE protein. Representative immunoblots from three independent experiments are shown. (B) Relative expression of CSE protein. The relative intensity was calculated by comparing with the intensity of $\beta$-actin using densitometry. The $\mathrm{Y}$ co-ordinate indicates the grey value of CSE normalized to that of $\beta$-actin. (C) Hydrogen sulfide $\left(\mathrm{H}_{2} \mathrm{~S}\right)$ levels in the cell culture media were measured. " $\mathrm{P}<0.05$, vs. the control group. ${ }^{.} \mathrm{P}<0.05$, vs. the TGF- $\beta 1$ group.

and the results revealed that TGF- $\beta 1$ significantly increased the invasion index of MCF-7 cells $(\mathrm{P}<0.05)$. NaHS treatment following TGF- $\beta$ administration significantly decreased the invasion index compared with that of cells treated with TGF- $\beta$ only ( $\mathrm{P}<0.05$, Fig. $2 \mathrm{~A})$. However, compared with control cells, NaHS treatment alone made no significant difference to the invasion index.

To investigate whether the EMT process is involved in the anti-invasive effect of NaHS, western blot analysis was performed to determine the expression of an EMT marker, Snail protein. TGF- $\beta 1$ treatment significantly induced EMT in MCF-7 cells, as evidenced by increased expression of Snail protein. Following NaHS treatment, TGF- $\beta 1$-induced Snail protein expression was significantly decreased. However, compared with control MCF-7 cells, Snail protein levels remained unchanged in cells treated with $\mathrm{NaHS}$ alone (Fig. 2B and C).

NaHS increases CSE protein expression and supernatant $\mathrm{H}_{2} \mathrm{~S}$ levels. The expression of CSE protein in TGF- $\beta 1$-induced MCF-7 cells was significantly increased by NaHS treatment. Moreover, 
A

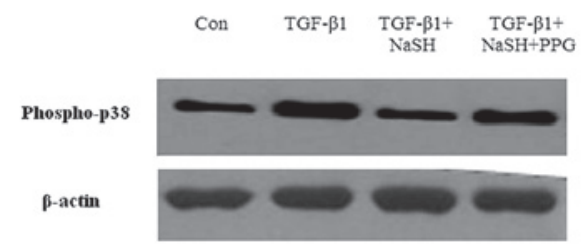

B

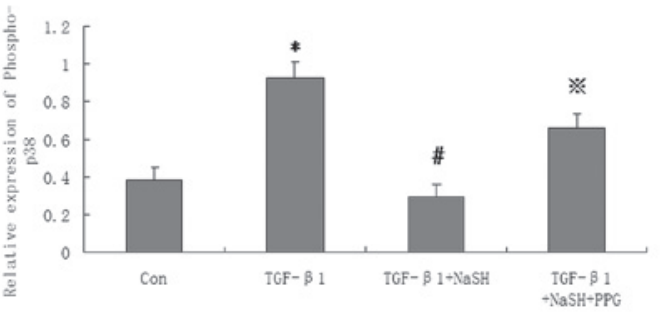

Figure 4. Sodium hydrosulfide (NaHS) decreased phospho-p38 protein expression in MCF-7 breast cancer cells. MCF-7 cells were pretreated with DL-propargylglycine (PPG, an inhibitor of cystathionine $\gamma$-lyase; $100 \mu \mathrm{mol} / \mathrm{l}$ ) for $1 \mathrm{~h}$, then incubated as control, transforming growth factor- $\beta 1$ (TGF- $\beta 1$, $100 \mathrm{ng} / \mathrm{ml})$, TGF- $\beta 1+\mathrm{NaHS}(500 \mu \mathrm{mol} / \mathrm{l})$ and TGF- $\beta 1+\mathrm{NaHS}+\mathrm{PPG}$ groups for $24 \mathrm{~h}$. Whole cell extracts were immunoblotted with the antibody against phospho-p38. $\beta$-actin served as a loading control. (A) Protein expression of phospho-p38 MAPK in MCF-7 cells. One representative figure is shown from three independent experiments. (B) The density of each band was converted into grayscale values and normalized to that of the internal control $\beta$-actin. Results are expressed as the mean \pm standard deviation. Phospho-p38 protein expression was significantly increased by TGF- $\beta 1$ compared with the control group $(\mathrm{P}<0.05)$. NaHS treatment decreased phospho-p38 protein expression in TGF- $\beta 1$-treated cells, which was increased by PPG pretreatment. " $\mathrm{P}<0.05$, vs. the control group. ${ }^{\prime} \mathrm{P}<0.05$ vs. the TGF- $\beta 1$ group. ${ }^{*} \mathrm{P}<0.05$, vs. the NaHS group.

the CSE protein level was decreased following TGF- $\beta 1$ treatment alone (Fig. 3A and B). To investigate whether an enhanced CSE protein level produces a greater level of endogenous $\mathrm{H}_{2} \mathrm{~S}$, the $\mathrm{H}_{2} \mathrm{~S}$ levels in the cell culture media were measured. The $\mathrm{H}_{2} \mathrm{~S}$ level in the cell culture media in cells treated with $100 \mathrm{ng} / \mathrm{ml}$ TGF- $\beta 1$ was significantly decreased in comparison with the control cells $(\mathrm{P}<0.05)$. When compared with the TGF- $\beta 1$-treated cells, the cells treated with NaHS had a significantly higher $\mathrm{H}_{2} \mathrm{~S}$ level at all concentrations of NaHS ( $\mathrm{P}<0.05$, Fig. 3C). These results indicate that the anticancer effect of NaHS may be mediated by activation of the $\mathrm{CSE} / \mathrm{H}_{2} \mathrm{~S}$ pathway.

NaHS decreases p38 mitogen-activated protein kinase (MAPK) phosphorylation in MCF-7 cells stimulated by $T G F-\beta 1$. To investigate the underlying signaling pathways in NaHS-treated MCF-7 cells, the expression of phospho-p38 MAPK, a signaling protein associated with apoptosis and EMT, was investigated. The MCF-7 cells were pretreated with PPG (an inhibitor of CSE, $100 \mu \mathrm{mol} / \mathrm{l}$ ) for $1 \mathrm{~h}$, then administered either TGF- $\beta 1(100 \mathrm{ng} / \mathrm{ml})$, TGF- $\beta 1+\mathrm{NaHS}(500 \mu \mathrm{mol} / \mathrm{l})$ or TGF- $\beta 1+N a H S+P P G$, and incubated for $24 \mathrm{~h}$. Western blot analysis revealed that TGF- $\beta 1$ significantly increased phospho-p38 protein expression. However, NaHS significantly decreased the phospho-p38 protein levels in MCF-7 cells treated with TGF- $\beta 1$, which was attenuated by PPG pretreatment (Fig. 4).

\section{Discussion}

In the present study, NaHS (a bioactive compound releasing $\mathrm{H}_{2} \mathrm{~S}$ ) exhibited anticancer effects in TGF- $\beta 1$-treated MCF-7 breast cancer cells, demonstrated by the inhibition of cell proliferation, cell cycle arrest in G0/G1 phase and induction of apoptosis. NaHS treatment also inhibited tumor invasion and decreased protein expression of an EMT marker, Snail. The underlying mechanisms may be associated with increased endogenous CSE protein expression and decreased p38 MAPK phosphorylation in MCF-7 cells stimulated by TGF- $\beta 1$ following NaHS administration.

The anticancer effects of exogenous $\mathrm{H}_{2} \mathrm{~S}$ on breast cancer cells indicate a novel therapeutic strategy for breast cancer. NaHS was revealed to reduce cell viability in a dose- and time-dependent manner, and the detailed mechanism lies in G0/G1 cell cycle arrest and induction of apoptosis. These results are in accordance with another study, which revealed that $\mathrm{H}_{2} \mathrm{~S}$-releasing aspirin decreased tumor mass through inhibition of cell proliferation and induction of G0/G1 arrest in estrogen receptor-negative breast cancer cells (7). In the present study, $\mathrm{NaHS}$, which is an exogenous $\mathrm{H}_{2} \mathrm{~S}$-releasing molecule and one form of $\mathrm{H}_{2} \mathrm{~S}$ in mammalian tissues, was used, therefore providing additional evidence regarding the anticancer effects of $\mathrm{H}_{2} \mathrm{~S}$. In a variety of pathological conditions, $\mathrm{H}_{2} \mathrm{~S}$ has been found to exhibit potent antiapoptotic effects including in hypoxia-induced mouse hippocampal neurons (15), high-glucose-induced rat cardiomyocytes (16) and hepatic ischemia/reperfusion injury (17). However, in the present study, NaHS was found to exhibit a potent apoptotic effect on breast cancer cells, particularly in cells treated with TGF- $\beta 1$. This contradiction may be a result of differences in the reaction to $\mathrm{H}_{2} \mathrm{~S}$ between non-tumor cells and tumor cells as $\mathrm{H}_{2} \mathrm{~S}$ has also been demonstrated to mediate the antisurvival effect of sulforaphane in human prostate cancer cells (18). Therefore, there may be benefits in introducing $\mathrm{H}_{2} \mathrm{~S}$-releasing therapeutic agents in the treatment of cancer.

In the present study, $\mathrm{H}_{2} \mathrm{~S}$ was found to have an inhibitory effect on invasion and EMT in breast cancer cells. EMT is a complex, multi-step process that involves epithelial cells developing a malignant phenotype, including invasive, migratory and metastatic capabilities (19). MCF-7 cells were incubated with TGF- $\beta 1$ to induce the EMT state, significantly increasing the invasion index of the cells and increasing the protein expression of an EMT marker, Snail. NaHS was revealed to significantly decrease this invasion index and the expression of Snail protein in the MCF-7 cells induced by TGF- $\beta$. This finding is in accordance with another study, which observed that $\mathrm{H}_{2} \mathrm{~S}$ inhibited EMT in human alveolar epithelial cells, demonstrated by decreased vimentin expression and increased E-cadherin expression (11). EMT is a vital process in driving epithelial cells to acquire a malignant phenotype and invasive properties (20). The results of the present study indicate that NaHS suppressed invasion through inhibition of the EMT process in MCF-7 cells. It was also found that tumor invasion and Snail protein expression remained unchanged following NaHS treatment in control MCF-7 cells without TGF- $\beta 1$. This indicates that compared with breast cancer cells without metastasis, NaHS may demonstrate an enhanced effect on the metastasis and EMT of breast cancer cells, thereby providing further evidence for the causal link between EMT and invasion in TGF- $\beta 1$-treated MCF-7 cells.

In the present study, NaHS increased CSE protein expression and supernatant $\mathrm{H}_{2} \mathrm{~S}$ levels. $\mathrm{H}_{2} \mathrm{~S}$ can be generated by CSE with L-cysteine as its substrate. Increased expression of CSE protein following NaHS administration indicates that the 
anticancer effect of NaHS not only depend on direct change from $\mathrm{NaHS}$ to $\mathrm{H}_{2} \mathrm{~S}$ in extracellular fluid, but also may be mediated by activation of the $\mathrm{CSE} / \mathrm{H}_{2} \mathrm{~S}$ pathway, thereby acquiring a more durable effect. The elevated $\mathrm{H}_{2} \mathrm{~S}$ level in the culture media provides further evidence that the $\mathrm{CSE} / \mathrm{H}_{2} \mathrm{~S}$ pathway instigates the anticancer effects of NaHS. In fact, a number of $\mathrm{H}_{2} \mathrm{~S}$-releasing drugs may produce their effects through activation of the $\mathrm{CSE} / \mathrm{H}_{2} \mathrm{~S}$ pathway. For example, one $\mathrm{H}_{2} \mathrm{~S}$ donor, S-propargyl-cysteine, exhibits its anticancer effect by increasing CSE protein expression in gastric cancer cells (21).

In order to investigate the detailed mechanisms underlying the inhibitory effect of $\mathrm{H}_{2} \mathrm{~S}$ on invasion and EMT in TGF- $\beta 1$-treated MCF-7 cells, the expression of a signal protein associated with apoptosis and invasion was measured. TGF- $\beta 1$ treatment alone increased phospho-p38 protein expression, but the addition of NaHS decreased the expression of phospho-p38 in TGF- $\beta 1$-treated cells. A previous study found that p38 MAPK promoted successful invasion and metastasis in tumor cells (22). p38 MAPK activation has also been demonstrated to mediate TGF- $\beta 1$-induced EMT in A549 alveolar epithelial cells (23), which is in accordance with the results of the present study. The inhibition of p38 MAPK has been found to reverse the EMT process and may be a potential therapeutic strategy to decrease cancer invasion (24). Therefore, decreased phospho-p38 may be an underlying mechanism for the inhibition of EMT by NaHS. To further confirm the inhibition of phospho-p38 by the $\mathrm{CSE} / \mathrm{H}_{2} \mathrm{~S}$ pathway, MCF-7 cells were pretreated with PPG (an inhibitor of CSE) then incubated with TGF- $\beta 1$ and NaHS. The decrease in phospho-p38 expression in TGF- $\beta 1$-treated MCF-7 cells following administration of NaHS was significantly attenuated by PPG. These results suggest a novel mechanism for the anticancer effects of exogenous $\mathrm{H}_{2} \mathrm{~S}$ via $\mathrm{CSE} / \mathrm{H}_{2} \mathrm{~S}$-induced inhibition of cell growth, induction of apoptosis, and the inhibition of invasion and EMT.

The detailed association between p38 MAPK and EMT remains unknown. One study demonstrated that the $\mathrm{p} 38 / \mathrm{NF}-\kappa \mathrm{B} / \mathrm{Snail}$ pathway was involved in the caffeic acid-induced inhibition of the migratory capacity of malignant human keratinocytes (25). This suggests that inhibition of NF- $\kappa B$ may mediate the causal association between decreased phospho-p38 expression and reduced EMT by NaHS, which warrants further investigation. The anticancer effect of NaHS and the potential $\mathrm{CSE} / \mathrm{H}_{2} \mathrm{~S}$ pathway also require further verification in animal models.

In conclusion, the results of the present study demonstrate that an $\mathrm{H}_{2} \mathrm{~S}$ donor, NaHS, exhibits anticancer effects on breast cancer cells, as evidenced by inhibition of proliferation, induction of apoptosis, and the inhibition of invasion and EMT. The underlying mechanisms of the NaHS anticancer effect may be through activation of the $\mathrm{CSE} / \mathrm{H}_{2} \mathrm{~S}$ pathway and decreased phospho-p38. These results suggest that exogenous $\mathrm{H}_{2} \mathrm{~S}$ may be a potential therapeutic strategy for breast cancer.

\section{References}

1. Renga B: Hydrogen sulfide generation in mammals: the molecular biology of cystathionine- $\beta$-synthase (CBS) and cystathionine- $\gamma$-lyase (CSE). Inflamm Allergy Drug Targets 10: 85-91, 2011.

2. Zhang LM, Jiang CX and Liu DW: Hydrogen sulfide attenuates neuronal injury induced by vascular dementia via inhibiting apoptosis in rats. Neurochem Res 34: 1984-1992, 2009.
3. Ahmad FU, Sattar MA, Rathore HA, et al: Exogenous hydrogen sulfide $\left(\mathrm{H}_{2} \mathrm{~S}\right)$ reduces blood pressure and prevents the progression of diabetic nephropathy in spontaneously hypertensive rats. Ren Fail 34: 203-210, 2012.

4. Qipshidze N, Metreveli N, Mishra PK, Lominadze D and Tyagi SC: Hydrogen sulfide mitigates cardiac remodeling during myocardial infarction via improvement of angiogenesis. Int J Biol Sci 8: 430-441, 2012.

5. Olson KR, Whitfield NL, Bearden SE, et al: Hypoxic pulmonary vasodilation: a paradigm shift with a hydrogen sulfide mechanism. Am J Physiol Regul Integr Comp Physiol 298: R51-R60, 2010.

6. Chattopadhyay M, Kodela R, Nath N, et al: Hydrogen sulfide-releasing NSAIDs inhibit the growth of human cancer cells: a general property and evidence of a tissue type-independent effect. Biochem Pharmacol 83: 715-722, 2012.

7. Chattopadhyay M, Kodela R, Nath N, Barsegian A, Boring D and Kashfi K: Hydrogen sulfide-releasing aspirin suppresses NF- $\mathrm{B}$ signaling in estrogen receptor negative breast cancer cells in vitro and in vivo. Biochem Pharmacol 83: 723-732, 2012.

8. Frantzias J, Logan JG, Mollat P, et al: Hydrogen sulphide-releasing diclofenac derivatives inhibit breast cancer-induced osteoclastogenesis in vitro and prevent osteolysis ex vivo. $\mathrm{Br}$ J Pharmacol 165: 1914-1925, 2012.

9. Daroqui MC, Vazquez P, Bal de Kier Joffé E, Bakin AV and Puricelli LI: TGF- $\beta$ autocrine pathway and MAPK signaling promote cell invasiveness and in vivo mammary adenocarcinoma tumor progression. Oncol Rep 28: 567-575, 2012.

10. Wendt MK, Smith JA and Schiemann WP: Transforming growth factor- $\beta$-induced epithelial-mesenchymal transition facilitates epidermal growth factor-dependent breast cancer progression. Oncogene 29: 6485-6498, 2010.

11. Fang LP, Lin Q, Tang CS and Liu XM: Hydrogen sulfide attenuates epithelial-mesenchymal transition of human alveolar epithelial cells. Pharmacol Res 61: 298-305, 2010.

12. Fang L, Li H, Tang C, Geng B, Qi Y and Liu X: Hydrogen sulfide attenuates the pathogenesis of pulmonary fibrosis induced by bleomycin in rats. Can J Physiol Pharmacol 87: 531-538, 2009.

13. Fan HN, Wang HJ, Ren L, et al: Decreased expression of p38 MAPK mediates protective effects of hydrogen sulfide on hepatic fibrosis. Eur Rev Med Pharmacol Sci 17: 644-652, 2013.

14. Fang LP, Lin Q, Tang CS and Liu XM: Hydrogen sulfide suppresses migration, proliferation and myofibroblast transdifferentiation of human lung fibroblasts. Pulm Pharmacol Ther 22: 554-561, 2009.

15. Luo Y, Liu X, Zheng Q, et al: Hydrogen sulfide prevents hypoxia-induced apoptosis via inhibition of an $\mathrm{H}_{2} \mathrm{O}_{2}$-activated calcium signaling pathway in mouse hippocampal neurons. Biochem Biophys Res Commun 425: 473-477, 2012.

16. Zhou X and Lu X: Hydrogen sulfide inhibits high-glucose-induced apoptosis in neonatal rat cardiomyocytes. Exp Biol Med (Maywood) 238: 370-374, 2013.

17. Bos EM, Snijder PM, Jekel H, et al: Beneficial effects of gaseous hydrogen sulfide in hepatic ischemia/reperfusion injury. Transpl Int 25: 897-908, 2012.

18. Pei Y,Wu B, Cao Q, Wu L and Yang G: Hydrogen sulfide mediates the anti-survival effect of sulforaphane on human prostate cancer cells. Toxicol Appl Pharmacol 257: 420-428, 2011.

19. Huber MA, Kraut N and Beug H: Molecular requirements for epithelial-mesenchymal transition during tumor progression. Curr Opin Cell Biol 17: 548-558, 2005.

20. Sánchez-Tilló E, Liu Y, de Barrios O, et al: EMT-activating transcription factors in cancer: beyond EMT and tumor invasiveness. Cell Mol Life Sci 69: 3429-3456, 2012.

21. Ma K, Liu Y, Zhu Q, et al: $\mathrm{H}_{2} \mathrm{~S}$ donor, S-propargyl-cysteine, increases CSE in SGC-7901 and cancer-induced mice: evidence for a novel anti-cancer effect of endogenous $\mathrm{H}_{2} \mathrm{~S}$ ? PLoS One 6: e20525, 2011.

22. del Barco Barrantes I and Nebreda AR: Roles of p38 MAPKs in invasion and metastasis. Biochem Soc Trans 40: 79-84, 2012.

23. Chen HH, Zhou XL, Shi YL and Yang J: Roles of p38 MAPK and JNK in TGF- $\beta 1$-induced human alveolar epithelial to mesenchymal transition. Arch Med Res 44: 93-98, 2013.

24. Antoon JW, Nitzchke AM, Martin EC, et al: Inhibition of p38 mitogen-activated protein kinase alters microRNA expression and reverses epithelial-to-mesenchymal transition. Int J Oncol 42: 1139-1150, 2013.

25. Yang Y,Li Y, Wang K, Wang Y, Yin W and Li L: P38/NF- $\kappa$ B/snail pathway is involved in caffeic acid-induced inhibition of cancer stem cells-like properties and migratory capacity in malignant human keratinocyte. PLoS One 8: e58915, 2013. 